\title{
DESASTRES E LOGÍSTICA HUMANITÁRIA
}

Quase todas as semanas, imagens de catástrofes, naturais ou provocadas pela ação do homem, invadem os canais de televisão, os jornais e são lugar-comum nas rádios. Em consequência, as pesquisas sobre gerenciamento de operações em desastres e logística humanitária têm crescido, em termos de publicação e importância, nos últimos anos. Operações humanitárias têm recebido crescente interesse, tanto de universitários quanto de profissionais de operações e logística, como resultado do aumento dramático nas catástrofes naturais e causadas pelo homem. 0 impacto sobre as populações afetadas pode ser bastante drástico, necessitando de operações de logística, em resposta a emergências, com eficiência e eficácia. Renata de Oliveira Silva, doutoranda na FGV-EAESP, professora da UMC e voluntária da ONG Médicos sem Fronteiras, apresenta cinco sugestões de leitura sobre o tema.

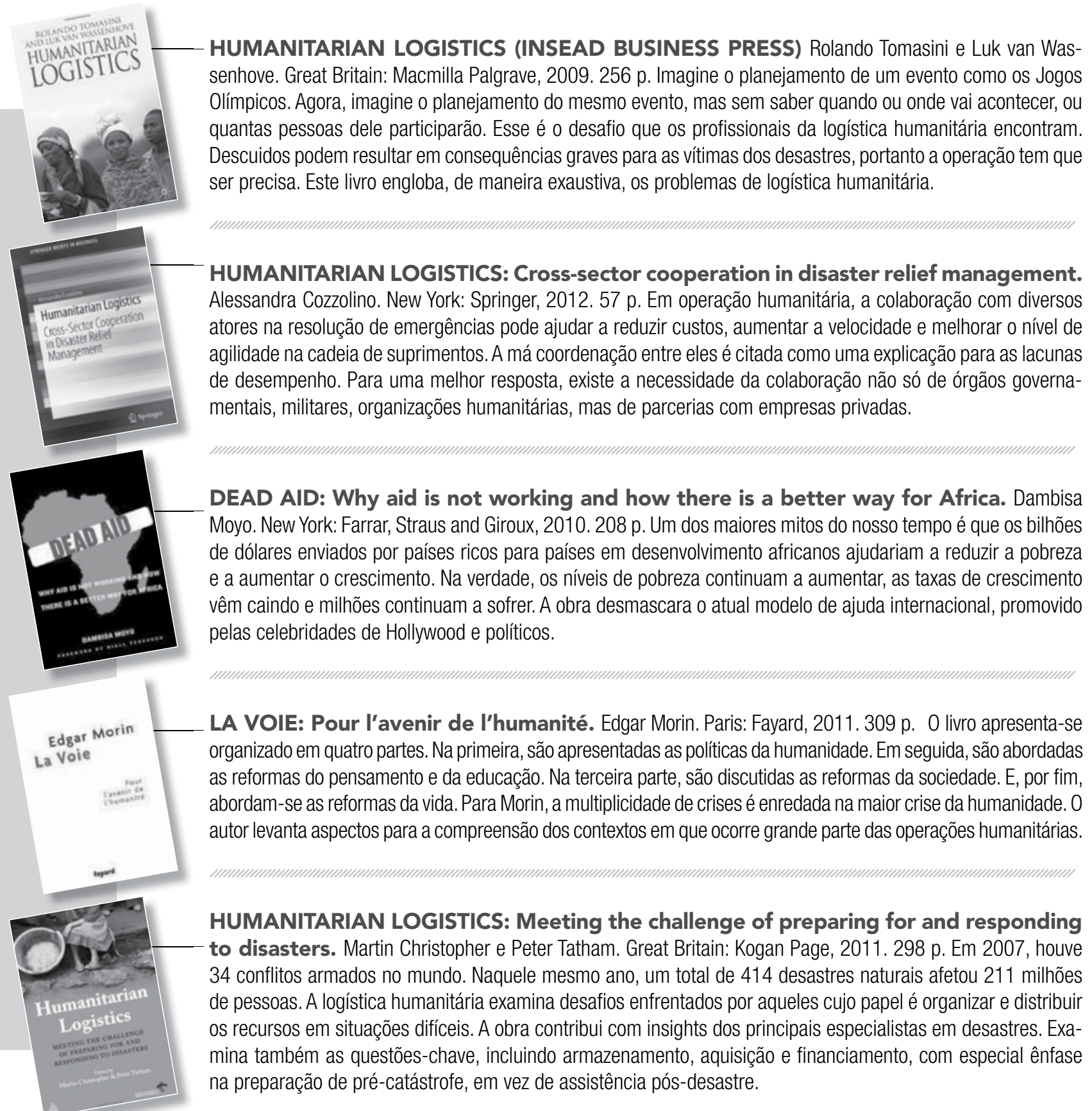

Renata de Oliveira Silva reoliveir@gmail.com 